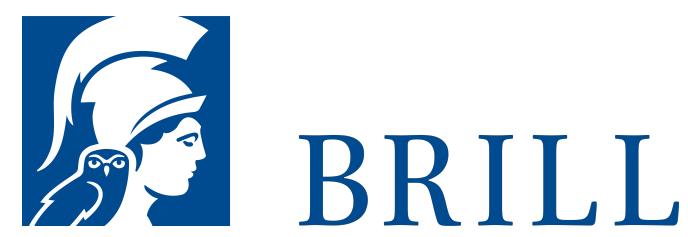

\title{
Noms propres du P.Bruxelles inv.E 7616
}

\section{Essai d'interprétation}

Author: Vergote

Language:

French

Subjects:

General,

Classical Studies

Publisher: Brill

\section{Series:}

Papyrologica

Lugduno-

Batava, Volume:

7

E-Book (PDF)

Released online: O2 Mar $202 \mathrm{O}$

ISBN: $978-90-$

O4-42997-O

List price

USD $\$ 42.00$

\section{Hardback}

Publication date: o1 Dec 1954

ISBN: 978-9004-42882-9 
For more information see brill.com

Order information: Order online at brill.com +44330 333 0049 | customerservices@brill.com Submission information: brill.com/authors

Titles published by Brill | Fink, Brill | mentis or Brill | Schöningh: +49(o)715413279216| brill@brocom.de 